Gut, 1965, 6, 85

\title{
Gastric fibroma with eosinophilic infiltration
}

\author{
R. SALM \\ From Camborne-Redruth Hospital, Redruth, Cornwall
}

EDITORIAL SYNOPSIS The possible significance of eosinophilic infiltration in a gastric tumour is exhaustively reviewed in this case report. An annotated bibliography is provided.

Benign gastric tumours are infrequent. In Eusterman and Senty's (1922) series they amounted to about $0.6 \%$ of all gastric neoplasms. A higher incidence has been observed by other workers. Lockwood (1932) encountered benign gastric neoplasms in $4.5 \%$ of his cases, Eliason and Wright (1925) in $4 \cdot 12 \%$, Marshall (1955) in $4.8 \%$, and Stout (1953) in $16.9 \%$ (the last high figure no doubt being due to selected material).

The majority of benign tumours of the stomach are epithelial in origin, and are either sessile adenomas or pedunculated papillomas. Some authors also include hypertrophic gastritis under this heading. Carcinoids should be regarded as malignant neoplasms (Lattes and Grossi, 1956).

The mesenchymal variants of benign gastric neoplasms, in descending order of frequency, are leiomyoma and neurilemoma (which are not always histologically separable), haemangioma, fibroma, and lipoma (Tanner, 1950).

Other benign tumours, such as ganglioneuroma (Dahl, Waugh, and Dahlin, 1957), dermoid (Balfour and Henderson, 1927; Tanner, 1950), teratoma (Willis, 1962), glomus tumour, granular cell myoblastoma, and lymphangioma (Stout, 1953), are so rare as to constitute curiosities. The gastric wall may also be involved in neurofibromatosis (Stout), and ectopic pancreatic tissue may form non-neoplastic mural masses.

Fibromas are considered to be rare. Thus Minnes and Geschickter (1936) found only one fibroma amongst 50, and Eusterman and Senty (1922) five fibromas amongst 27 benign gastric lesions. Stout (1953) does not list a single case of fibroma amongst 110 cases of benign gastric neoplasms, although mentioning four inflammatory polypi and five eosinophilic granulomas.

This paper records a submucous fibroma of the cardia.

\section{CASE REPORT}

M.D., a woman aged 54 years, was admitted in October 1963 complaining of epigastric pain not related to food, occasional sickness, and slight loss of weight for about one month. There was no history of dysphagia or haematemesis. Oesophagoscopy showed a polypoid tumour mass, $41 \mathrm{~cm}$. from the dental margin, at the posterior oesophageal wall. On barium swallow the presence of this growth at the cardia was confirmed (Fig. 1), which was thought to arise from the left lateral wall. A left thoracotomy was performed. A gastric tumour was palpable through the diaphragm, and a pedunculated growth was removed from the cardiac portion of the stomach by dividing its mucosal pedicle. The patient made an uneventful recovery.

OPERATION SPECIMEN The excised mass was ovoid in shape, with a smooth or finely granular, brownish discoloured surface, measuring $4.5 \times 4 \times 2.5 \mathrm{~cm}$. and weighing $25 \mathrm{~g}$. The cut surfaces were moderately firmelastic in consistency, yellowish-grey in colour, and moist and uniform in appearance (Fig. 2).

HISTOPATHOLOGY (63/2638) Four complete crosssections were cut through the mass. The sections from all blocks show a moderately vascular, centrally oedematous and slightly myxomatous, benign fibroblastic neoplasm. Diffuse infiltration with many oesinophil leucocytes is present throughout (Fig. 3), and there are scattered small lymphocytic aggregations. An occasional mucosal glandular tubule is met with encased in the fibroblastic mass.

The tumour tissue contains well-formed capillaries, veins, and small muscular arteries, which are occasionally moderately numerous and show up well in silver impregnations (Fig. 4). No relationship is demonstrable between vessel walls and the neoplastic fibroblasts which make up the bulk of the tissue. These are usually spindle-shaped, but towards the centre many are plump and swollen. Mitoses are absent. No capsule is discernible. Remnants of oesophageal wall and gastric mucosa, including muscularis mucosae, are present at the site of attachment to the cardia (Fig. 5), but elsewhere the surface of the tumour is eroded and is formed by a thin zone of active granulation tissue (Fig. 6) which is covered by polymorphic exudate.

Scanty intracellular mucin is demonstrable in the centre of the mass in alcian green stains. Trichrome stains prove the presence of scanty collagen but show no additional features and no nerve fibrils are demonstrable 


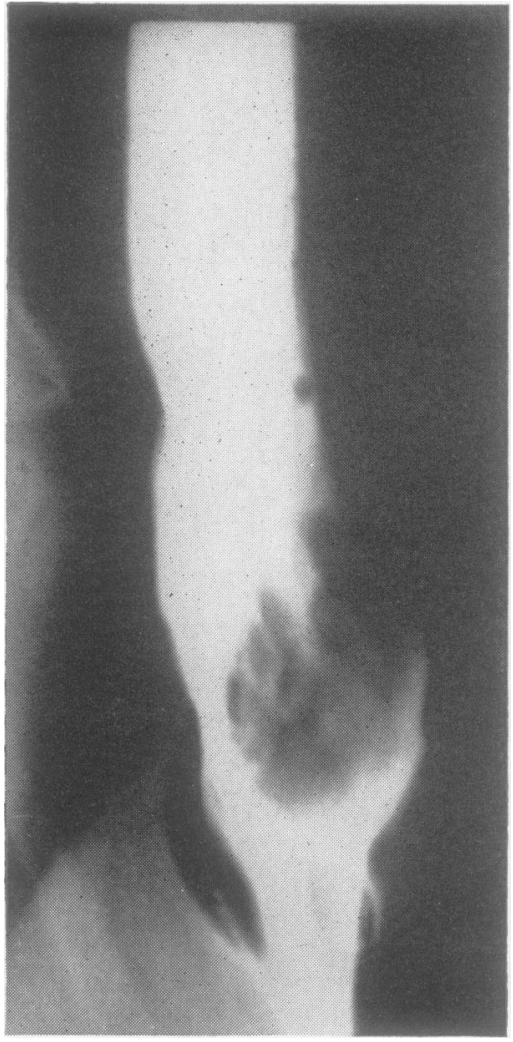

FIG. 1.

Barium swallow showing

large pedunculated mass at level of cardia.

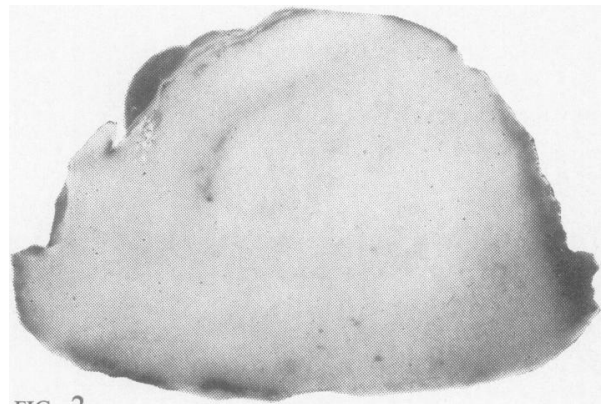

FIG. 2.

FIG. 2. Oedematous uniform appearances of bisected tumour (natural size).

FIG. 3. High-power field of loose-textured fibroblastic tumour with well-formed small capillaries and diffuse infiltration with numerous eosinophils. Haematoxylineosin $\times 375$.

FIG. 4. Silver impregnation showing regular reticulin framework and several incorporated blood vessels. $\times 120$.

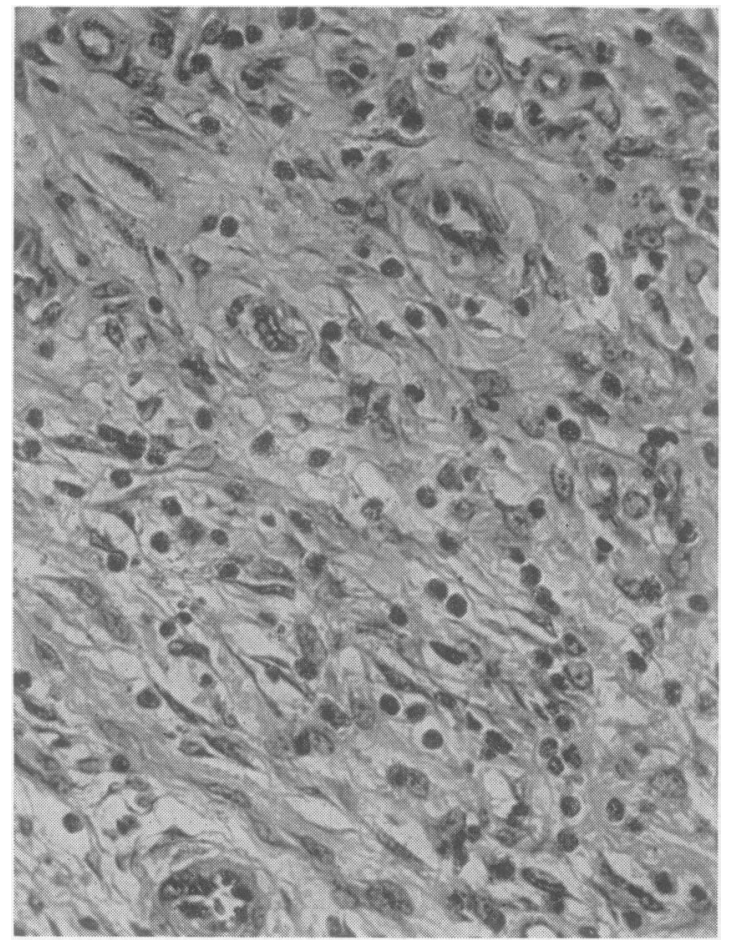

FIG. 3 .

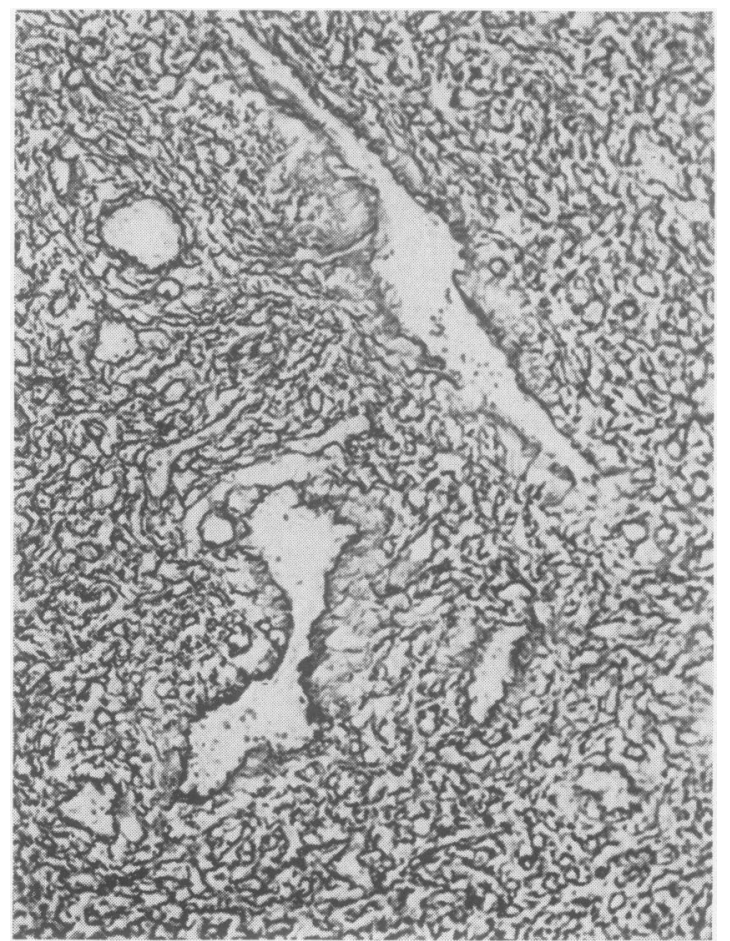

FIG. 4. 


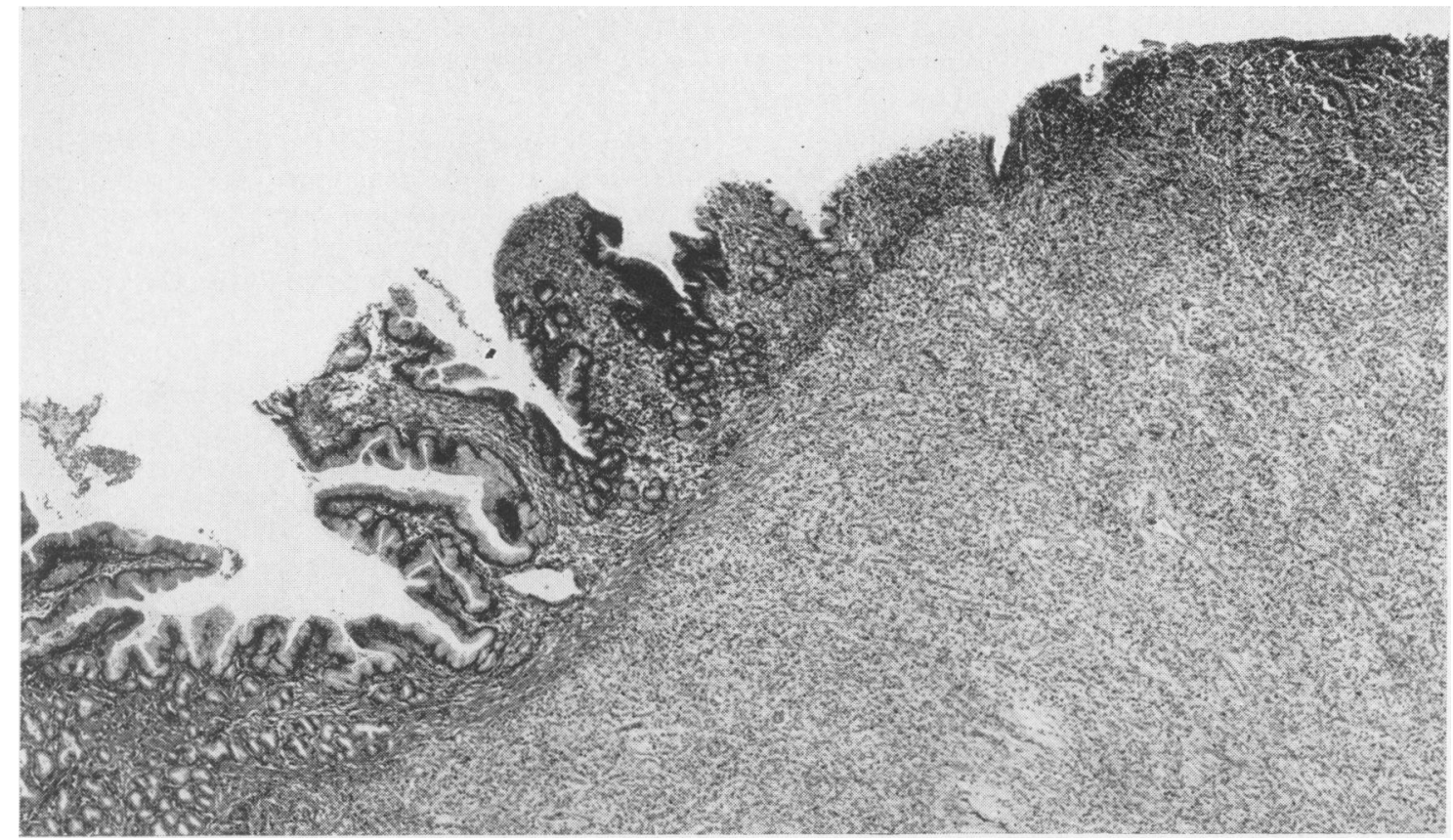

FIG. 5. Low-power view of tumour covered by gastric mucosa which has become eroded (top right) and is here covered by a zone of active granulation tissue. Haematoxylin and eosin $\times 32$.

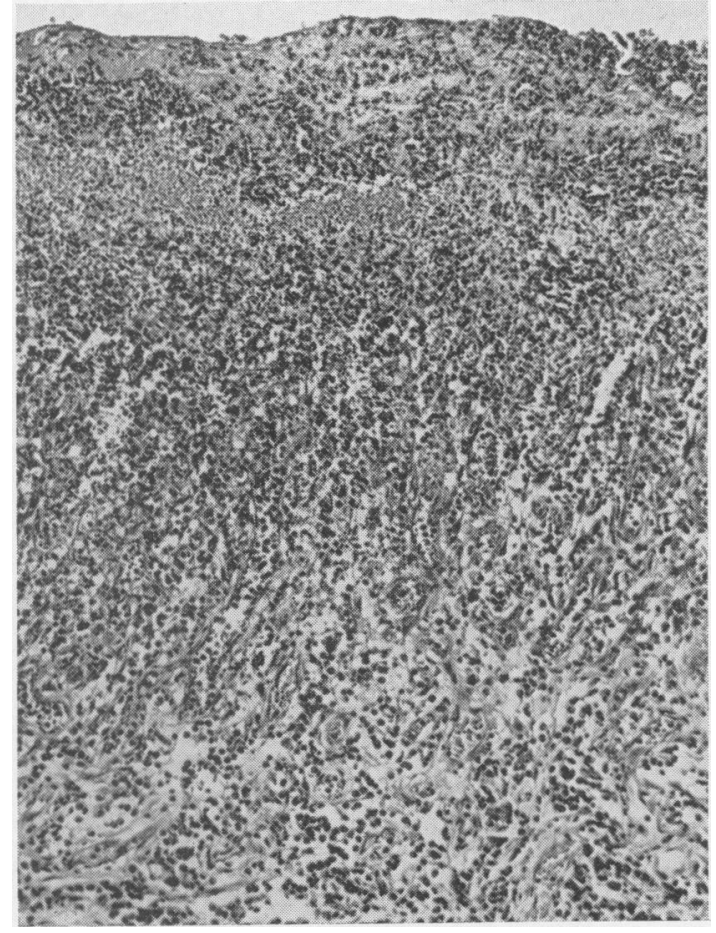

FIG. 6. High-power view of granulation tissue contrasting sharply with tumour tissue at bottom. Compare also with Figure 3. Haematoxylin and eosin $\times 120$. in the sections which were stained for axons (Holmes, 1947).

The muscularis mucosae is recognizable at the base, but fibroblastic proliferation has penetrated into the mucosal lamina propria above it. No elements of the gastric muscular coats are included in the specimen, and hence the growth has apparently involved mainly the gastric submucosa.

A diagnosis of pedunculated submucous fibroma of the cardia was made.

\section{DISCUSSION}

Konjetzny (1920) was probably the first to describe a pedunculated submucous gastric fibroma, and interpreted it correctly as a fibroma. Vaněk (1949) collected a series of six cases. After considering whether to regard them as granulomas or fibromas he finally called them eosinophilic granulomas. This was an unfortunate decision, for although Vaněk emphasized that the lesion was quite different from the eosinophilic granuloma of bone (Otani and Ehrlich, 1940), subsequent workers have speculated as to the possible links between gastric fibroma and eosinophilic granuloma of bone and skin, and even with Hand-Schüller-Christian disease. Vaněk himself admitted that the differential diagnosis of 'gastric eosinophilic granuloma' and gastric fibroma was difficult, and thought the gastric fibroma was probably the late result of a preceding granuloma. In the same year Bolck reported three gastric 
fibromas which he called 'granuloblastomas', as he thought that they were benign neoplasms arising from granulomatous foci. Other divergent conceptions are neurofibroma (Feyrter, 1949), haemangioendothelioma (Sawyer and Lubchenko, 1951), inflammatory fibroid polypi (Helwig and Ranier, 1953), haemangiopericytoma (Stout, 1953), and xanthofibroma (Berger, Shenoy, and Ames, 1962).

Stout (1953, p. 48) states that 'if a fibroma [of the stomach] occurs, the writer has never seen an example of it'. But his Figures 21 and 22 show a good example of a gastric fibroma, and represent one of the cases of Helwig and Ranier, which they regarded as inflammatory fibroid polypi. Though there is some evidence of a concentric perivascular arrangement of fibrous tissue, there is no evidence of a pericytoma.

Fifty-eight previously recorded unequivocal cases of gastric fibroma were traced in the literature and their main characteristics will be summarized.

AGE The age of the patients ranged from 22 to 90 years with a peak incidence in the sixth decade. The mean age was 55 years and $9 \frac{1}{2}$ months.

SEX DISTRIBUTION In one case the sex is unknown. Males predominated in an approximate proportion of $3: 2$, there being 36 males and 21 females. However, these figures may be somewhat biased owing to the inclusion of Helwig and Ranier's cases which were derived from the American Armed Forces. If these are excluded the proportion of males to females is $1.25: 1$.

CLINICAL SYMPTOMS Vague gastric symptoms and pain in the gastric area are the main symptoms. The length of history varied from three weeks to 20 years. Occasionally there was loss of weight; the E.S.R. was usually normal. Low haemoglobin values were associated with melaena. Absence of free hydrochloric acid or hypo-acidity was frequently observed on examination of the gastric juice, and when accompanied by an equivocal radiological picture was the reason for an erroneous clinical diagnosis of carcinoma. Eosinophilia of the peripheral blood was never demonstrable, except in case 2 of Frank (1953) who had a definite allergic diathesis.

RADIOLOGICAL FEATURES Radiological examination was most helpful in polypoid lesions, and pedunculated fibromas which had prolapsed into the duodenum have been visualized on several occasions. In the case of largely intramural lesions the radiological features have been less diagnostic, being reported as pyloric stenosis, ulcer craters, filling defects, or gastric carcinoma.

SITE In about four-fiths of the cases the fibromas were situated at or near the pylorus or in the antrum. In the remaining cases the tumour was present in the middle portion of the stomach. The present case would appear to be the first to occur at the cardia.

MACROSCOPICAL APPEARANCES The smaller lesions usually displayed well-delimited peripheries, clearly arose from and were confined to the submucosa, and were covered by gastric mucosa (Bolck, cases 1 and 3, 1949; Nunes, case 2, 1950; Smith, case 1, 1956). They presented as greyish or yellowish-grey, firm fibrous masses of spherical or ovoid outline, and many either projected into the gastric cavity or were entirely polypoidal. The mucosa over the larger growths was usually eroded. An occasional fibroma was adjoined at one side by a deeply excavated peptic ulcer (Vaněk, case 4, 1949; Nunes, case 3, 1950). A few fibromas remained confined to the submucosa, forming flat fibrous submucous plaques (Bolck, case 2, 1949; Schümann, 1952). Helwig and Ranier (case 10, 1953) recorded the occurrence of two polypoidal fibromas in one stomach.

HISTOPATHOLOGY The microscopical features are uniform. The lesions are made up of more or less densely arranged fibroblasts. The smaller masses are contained within the submucosa, but as the growths enlarge fibroblasts penetrate through the overlying muscularis mucosae into the mucosa itself, with erosion as a sequel. The muscular coats are usually not involved. The vascularity varies from fibroma to fibroma, and also within the individual tumour, but most contain areas with many well-formed arterioles, capillaries, veins, and lymphatics which can best be demonstrated in silver impregnations. Small scattered lymphocytic aggregations have been observed by many investigators. Diffuse infiltration with eosinophils has mostly, though not invariably, been present and has been the feature which misled many authors into regarding the lesion as inflammatory or granulomatous.

However, eosinophils can usually be found in moderate numbers in the normal mucosa of the gastrointestinal tract, and may be considerably increased in various disease processes (see below). Thus, unless they form the main constituent of a pathological process, such as in an eosinophilic abscess, their mere presence as a slight diffuse infiltrate cannot be regarded as of any special significance. 
Frequently, especially in pedunculated fibromas, the centre is oedematous and may be slightly myxomatous. This is not surprising as the pull exerted on the growth by the passage of food and by normal peristalsis must lead to interference with the blood supply and cause transudation of oedema fluid. Remaining gastric mucosal glands may be encountered within the fibroblastic mass, as already recorded by Konjetzny (1920). Mitoses are either absent or exceedingly scanty. Berger et al. (1962), like others before them, demonstrated the presence of small Sudan-positive intracytoplasmic droplets which induced them to regard the lesion as a 'xanthofibroma'. As mentioned above there have been a variety of other interpretations of this fibromatous lesion, for none of which adequate proof has been adduced by the authors.

INTESTINAL FIBROMATA Quite similar fibromas as described in the stomach have been recorded in the small gut. Only an abstract was available of Marek's (1954) case and Unnewehr and Ohrt's (1954) case lacked illustrations, but both are probably genuine cases. Kofler's (1952) case of caecal fibroma (case 8) is unconvincing.

TREATMENT Surgery has proved curative in all cases. Pedunculated fibromas are easily removed by dividing the mucosal pedicle. Largely intramural fibromas necessitate partial gastrectomy, according to Polya, in order to remove pyloric and antral, and, according to Billroth I, to remove fibromas of the central gastric zone.

DIFFERENTIAL DIAGNOSIS Although the microscopical features of this gastric tumour are thus quite distinct, in view of the widely divergent designations this growth has received in the past and the confusion with other disease entities which has arisen (Kofler, 1952; Ashby, Appleton, and Dawson, 1964; and others), it is necessary to separate it sharply from inflammatory conditions and hence the differential diagnosis will be briefly discussed.

Erosions and foreign-body granulomata The gastric lining becomes frequently eroded and ulcerated, yet genuine granulomata are observed but rarely. Kolodny (1935) reported a genuine granulomatous foreign-body reaction associated with peptic ulcer in two patients. Similar features were described in five cases by Sherman and Moran (1954) who were also able to produce such lesions experimentally (Moran and Sherman, 1954).

Crohn's disease Although regional enteritis involves mainly the ileum and large gut, segmental lesions may occur higher up in the gastrointestinal canal involving jejunum, duodenum, pylorus, and stomach. Such cases were recorded, for example, by Comfort, Weber, Baggenstoss, and Kiely (1950, cases 4 and 5), Goldgraber, Kirsner, and Raskin (1958, case 2), and Swarts and Young (1955, case 1), whose patient showed a blood eosinophilia of $24 \%$, and microscopically the diseased gut wall proved to be densely infiltrated with eosinophils.

Parasitic gastric granulomata Herrings, like other species of sea fish, may be infested with nematodes (Kahl, 1939). In some countries bordering on the North Sea it is customary to consume freshly caught herrings which have been exposed for only brief periods to coarse salt. Hence parasitic larvae from only slightly salted raw herrings may survive and may, when reaching the gastrointestinal canal, give rise to an intense, localized, phlegmonous inflammatory mass with very large numbers of eosinophils. Cases with gastric involvement have been described by Kuipers, van Thiel, Rodenburg, Wielinga, and Roskam (1960, case 13) and Voorhuis and Eijlers (1961), who demonstrated the presence of larvae of Eustoma rotundatum.

Nodular inflammatory foci The gastric wall is commonly not involved in cases of generalized infections. Equivocal non-caseating tuberculoid foci were found by Scott, Smith, Cox, and Palmer (1953) in the gastric mucosa in cases of sarcoidosis. Engle (1953) recorded gastric involvement in histoplasmosis (case 19) and in tuberculosis (case 26). Nodular epithelioid cell masses with central aggregation of giant cells were found by Boivin and Berry (1961) between mucosa and submucosa in a case of gastritis after reserpine therapy.

Gastric ulcer with marked eosinophilic infiltration Inflammatory infiltration of the tissues surrounding a peptic ulcer is usually present in varying degree. Occasionally the predominant cell is the eosinophil polymorph. Ortmayer, Balkin, and Humphreys (1946) and Goldgraber et al. (1958, case 3) described such cases. Their patients showed a moderate blood eosinophilia of 5 and $9 \%$ respectively, and hence it is possible that the concentration of eosinophils around the ulcer crater was due to an associated allergic predisposition, similar for example to the eosinophilic prostatitis occurring in asthmatics (Stewart, Wray, and Hall, 1954).

Non-specific eosinophilic granulomata These are of unknown aetiology, rather rare, and usually involve the large intestines. In Menendez and Tapia's case (1952) the ascending colon was the seat of an annular granuloma, $90 \%$ of the cells being eosinophils, although there were only $2 \%$ in the peripheral blood. De Santis (1954) described a large caecal eosinophilic granuloma. And Virshup and Mandelberg (1954) reported a case with obstruction of the mid-ileum by a large granulomatous mass with 
extensive eosinophilic infiltration and a blood eosinophilia of $20 \%$. Similar pseudo-tumours have apparently not been observed in the stomach. On account of their large size these eosinophilic granulomas have not been thoroughly studied. Thus it may well be that they are of parasitic origin and that serial step sections would reveal the presence of larvae amongst the mass of eosinophilic granulomatous tissue, similar to Ashton's (1960) experience with the occasional Toxocara canis granuloma of the eye.

Diffuse eosinophilic gastritis and/or enteritis Twenty-five cases of this type were found in the literature. There was an excess of males over females in a proportion of $3: 2$, the pre-operative history usually varied from several months to 16 years, an allergic background was elicited in 11 cases, and 18 cases showed a marked eosinophilia of the peripheral blood varying from 10 to $63 \%$. In 14 cases the abnormality was confined to the stomach, in three to the small gut, in seven cases there were gastric as well as small gut lesions, and in one case the omentum was also involved. At laparotomy the diseased segments were congested, acutely inflamed and greatly thickened, the gastrointestinal wall measuring from 1 to $2.4 \mathrm{~cm}$. in diameter, and on histological examination all coats, and in particular submucosa and muscularis, displayed diffuse eosinophilic infiltration. The aetiology of the lesion is still obscure. Ashby et al. (1964) suggested that many cases of eosinophilic gastro-enteritis are an allergic phenomenon following repeated infection with fish nematodes, but proof of this is entirely lacking.

A single case of eosinophilic colitis is on record (Dunstone, 1959). Apart from its localization the features were identical to those of the stomach and small gut.

It is this group that has in the past often been confused with the gastric fibroma solely on account of the presence of eosinophils in both lesions. But apart from this feature the two conditions have nothing in common. Clinically eosinophilic gastritis is associated with a raised E.S.R., a marked eosinophilia of the peripheral blood, there is frequently an allergic factor, and already on naked-eye examination it is clear that this is a diffuse inflammatory condition, contrasting sharply with the welldelimited and often pedunculated appearance of the gastric fibroma. When its covering gastric mucosa becomes eroded it is lined by active granulation tissue, which forms a marked contrast to the fibroblastic bulk of the tumour.

It is a pleasure to acknowledge my indebtedness to Professor R. A. Willis for his helpful advice and for reading the manuscript. I am obliged to $\mathrm{Mr}$. $\mathrm{H}$. V.
Wingfield for the clinical data. The photomicrographs are the work of Mr. E. V. Willmott and Figs. 1 and 2 were taken by Miss Phyllis E. Coleman.

\section{BIBLIOGRAPHY}

Ashton, N. (1960). Larval granulomatosis of the retina due to Toxocara. Brit. J. Ophthal., 44, 129-148.

Balfour, D. C., and Henderson, E. F. (1927). Benign tumors of the stomach. Ann. Surg., 85, 354-359.

Boivin, J. C., and Berry, G. (1961). Nonspecific granulomatous disease of the stomach with haematemesis following reserpine therapy. Canad. med. Ass. J., 84, 1444.

Comfort, M. W., Weber, H. M., Baggenstoss, A. H., and Kiely, W. F. (1950). Nonspecific granulomatous inflammation of the stomach and duodenum: its relation to regional enteritis. Amer. J. med. Sci., 220, 616-632.

Dahl, E. V., Waugh, J. M., and Dahlin, D. C. (1957). Gastrointestinal ganglioneuromas: brief review with report of a duodenal ganglioneuroma. Amer. J. Path., 33, 953-965.

Dunstone, G. H. (1959). A case of eosinophilic colitis. Brit. J. Surg., 46, 474-476.

Eliason, E. L., and Wright, V. W. M. (1925). Benign tumors of the stomach. Surg. Gynec. Obstet., 41, 461-472.

Engle, R. L. Jr. (1953). Sarcoid and sarcoid-like granulomas: a study of twenty-seven post-mortem examinations. Amer. J. Path., 29, 53-69.

Eusterman, G. B., and Senty, E. G. (1922). Benign tumors of the stomach. Surg. Gynec. Obstet., 34, 5-15.

Feyrter, F. (1949). Über die vasculäre Neurofibromatose, nach Untersuchungen am menschlichen Magen-Darmschlauch. Virchows Arch. path. Anat., 317, 221-265.

Goldgraber, M. B., Kirsner, J. B., and Raskin, H. F. (1958). Nonspecific granulomatous disease of the stomach. Arch. intern. Med., 102, 10-24.

Holmes, W. (1947). In Recent Advances in Clinical Pathology, edited by S. C. Dyke, p. 404. Churchill, London.

Kahl, W. (1939). Nematoden in Seefischen. II. Erhebungen über den Befall von Seefischen mit Larven von Anacanthocheilus rotundatus (Rudolphi) und die durch diese Larven hervorgerufenen Reaktionen des Wirtsgewebes. Z. Parasitenk., 10, 513534.

Kolodny, A. (1935). Infective granuloma of stomach. Ann. Surg., 102, 30-33.

Kuipers, F. C., van Thiel, P. H., Rodenburg, W., Wielinga, W. J., and Roskam, R. T. (1960). Eosinophilic phlegmon of the alimentary canal caused by a worm. Lancet, $2,1171-1173$.

Lattes, R., and Grossi, C. (1956). Carcinoid tumors of the stomach. Cancer (Philad.), 9, 698-711.

Lockwood, B. C. (1932). Benign tumors of the stomach. J. Amer. med. Ass., 98, 969-973.

Marshall, S. F. (1955). Gastric tumors other than carcinoma. Surg. Clin. N. Amer., 35, 693-702.

Menendez, V. P., and Tapia, I. R. (1952). Granuloma eosinofilo del colon. Arch. Hosp. univ. (Habana), 4, 248-253.

Minnes, J. F., and Geschickter, C. F. (1936). Benign tumors of the stomach. Amer. J. Cancer, 28, 136-149.

Moran, T. J., and Sherman, F. E. (1954). Granulomas of stomach. II. Experimental production by intramural injection of foreign material including gastric juice. Amer. J. clin. Path., 24, 422-433.

Ortmayer, M., Balkin, R., and Humphreys, E. (1946). Chronic erosive, granulomatous, atrophic gastritis. Gastroenterology, 6, 298-301.

Otani, S., and Ehrlich, J. C. (1940). Solitary granuloma of bone simulating primary neoplasm. Amer. J. Path., 16, 479-490.

de Santis, M. (1954). Granuloma eosinofilo del cieco. Il Policlinico, Sez. prat., 61, 1521-1527.

Scott, N. M. Jr., Smith, V. M., Cox, P. A., and Palmer, E. D. (1953). Sarcoid and sarcoid-like granulomas of the stomach. Arch. intern. Med., 92, 741-749.

Sherman, F. E., and Moran, T. J. (1954). Granulomas of stomach I. Response to injury of muscle and fibrous tissue of wall of human stomach. Amer. J. clin. Path., 24, 415-421.

Stewart, M. J., Wray, S., and Hall, M. (1954). Allergic prostatitis in asthmatics. J. Path. Bact., 67, 423-430.

Stout, A. P. (1953). Tumors of the Stomach (Atlas of Tumor Pathology, pp. 10, 46 and 48. Section VI, Fascicle 21). Published by the Armed Forces Institute of Pathology, Washington, D.C. 
S warts, J. M., and Young, J. M. (1955). Primary infiltrative eosinophilic gastritis, enteritis and peritonitis. Gastroenterology, 28, 431-452.

Tanner, N. C. (1950). In British Surgical Practice, edited by E. R. Carling and J. P. Ross, p. 55, vol. 8. Butterworth, London.

Virshup, M., and Mandelberg, A. (1954). Eosinophilic granuloma of the gastrointestinal tract. Ann. Surg., 139, 236-240.

Voorhuis, F. J., and Eijlers, W. (1961). Een ontstekingstumor van de maag, waarschijnlijk veroorzaakt door de haringworm. Ned. T. Geneesk., 105, 2542-2545.

Willis, R. A. (1962). The Pathology of the Tumours of Children, p. 89. Oliver and Boyd, Edinburgh and London.

SUBMUCOUS GASTRIC FIBROMAS

Berger, L., Shenoy, Y. M. V., and Ames, S. (1962). Xanthofibroma of stomach. N.Y. St. J. Med., 62, 2032-2035.

Bolck, F. (1949). Die Granuloblastome des Magens. Beitr. path. Anat., $110,635-660$.

Booher, R. J., and Grant, R. N. (1951). Eosinophilic granuloma of the stomach and small intestine. Surgery, 30, 388-397.

Bullock, W. K., and Moran, E. T. (1953). Inflammatory fibroid polyps of the stomach. Cancer, (Philad.) 6, 488-493.

Fiedler, H. H. (1954). Ein klinischer Beitrag zum sog. Granuloblastom des Magens. Z $\mathrm{bl}$. Chir., 79, I, 584-587.

Fischer, H. G. (1956). Das eosinophilie Granulom des Magens. Chirurg, 27, 516-519.

Frank, A. (1953). Uber das eosinophile Granulom des Magens. Gastroenterologia (Basel), 80, 9-20.

Helwig, E. B., and Ranier, A. (1953). Inflammatory fibroid polyps of the stomach. Surg. Gynec. Obstet., 96, 355-367.

Knieriem, W. (1951). Uber Granuloblastome des Magens. Arch. Langenbecks. klin. Chir., 270, 111-116.

Koch, W., Stockmeyer, E., and Apablaza, H. (1958). Eosinophilic granuloma of the stomach. Amer. J. Roentgenol., 80, 54-56.

Kofler, E. (1952). Über die Granulome des Magen-Darmschlauches. Virchows Arch. path. Anat., 321, 121-133.

Konjetzny, G. E. (1920). Ueber Magenfibrome. Bruns Beitr. klin. Chir., 119, 53-61.

Nunes, M. A. (1950). Granuloma (granuloblastoma) gástrico submucoso com eosinófilos. Gaz. med. Port., 3, 751-759.

Rigler, K. G., Blank, L., and Hebbel, R. (1956). Granuloma with eosinophils: benign inflammatory fibroid polyps of the stomach. Radiology, 66, 169-176.

Sauter, K. E., and Pessin, B. J. (1962). Intermittent pyloric obstruction due to prolapse of an inflammatory fibroid polyp of the stomach. Wis. med. J., 61, 175-180.

Sawyer, K. C., and Lubchenko, A. E. (1951). Hemangioendothelioma of the stomach. Surgery, 30, 383-387.

Schümann, H. (1952). Klinischer und pathologisch-anatomischer Beitrag zum sog. Granuloblastom des Magens. Langenbecks Arch. klin. Chir., 271, 139-144.

Smith, M. J. (1956). Gastric granuloma with eosinophilic infiltration. Radiology, 66, 177-180.

Tavernari, A. (1955). Granulomi e granuloblastomi eosinofili dello stomaco. Arch. ital. Chir., 80, 337-384.

Toole, H. J., and Moschopoulos, A. N. (1959).Eosinophilic granuloma of the gastrointestinal tract: report of two cases. Brit. J. Surg., 46, 445-448.

Vaněk, J. (1949). Gastric submucosal granuloma with eosinophilic infiltration. Amer. J. Path., 25, 397-411.

SUBMUCOUS INTESTINAL FIBROMAS

Kofler, E. (1952). Uber die Granulome des Magen-Darmschlauches. Virchows. Arch. path. Anat., 321, 121-133.

Marek, S. (1954). Eosinofilni granulom tenkého střeva. (Eosinophilic granuloma of the small intestine.) Cas. lék. ces., 93, 484. (Abstr., Excerpta med. (Amst.), Sect. IX., 8, 7748.)
Polayes, S. H., and Krieger, J. L. (1950). Eosinophilic granuloma of the jejunum. J. Amer. med. Ass., 143, 549-551.

Toole, H. J., and Moschopoulos, A. N. (1959). Eosinophilic granuloma of the gastrointestinal tract: report of two cases. Brit. J. Surg., 46, 445-448.

Unnewehr, F., and Ohrt, H. (1954). Eosinophiles Granulom des Dünndarms als Ursache für einen Ileus. Zbl. Chir., 79, 91-93.

EOSINOPHILIC GASTRITIS AND/OR ENTERITIS

Ashby, B. S., Appleton, P. J., and Dawson, I. (1964). Eosinophilic granuloma of gastrointestinal tract caused by herring parasite Eustoma rotundatum. Brit. med. J., 1, 1141-1145.

Barnett, L. A., and Kazmann, H. A. (1952). Gastric granuloma with eosinophilic infiltration. Amer. J. Surg., 84, 107-110

Barrie, H. J., and Anderson, J. C. (1948). Hypertrophy of the pylorus in an adult with massive eosinophil infiltration and giant-cell reaction. Lancet, 2, 1007-1009.

Blackwell, J. B., and Gild, A. (1962). Eosinophilic infiltration of the stomach: review of the literature and case report. Austr. N.Z. J. Surg., 32, 66-74.

Cantor, M. O. (1959). Obstructing eosinophilic granuloma of the stomach associated with arteriomesenteric duodenal compression. J. int. Coll. Surg., 31, 281-285.

Doniach, I., and McKeown, K. C. (1951). A case of eosinophilic gastritis. Brit. J. Surg., 39, 247-250.

Edelman, M. J., and March, T. L. (1964). Eosinophilic gastroenteritis. Amer. J. Roentgenol., 91, 773-778.

Ferrier, T., and Davis, N. (1957). Eosinophilic infiltration of stomach and small intestine. Med. J. Austrl., 1, 789-791.

Herrera, J. M., and de la Guardia, J. (1948). Un raro caso de eosinofilia gastro-intestinal motivadora de un cuadro organico de estenosis pilorica. Arch. Hosp. (Santo Tomas), 3, 19-34.

Judd, C. S., Jr., Civin, W. H., and McIlhany, M. L. (1955). Eosinophilic granuloma of the stomach. Gastroenterology, 28, 453-457.

Kaijser, R. (1937). Zur Kenntnis der allergischen Affektionen des Verdauungskanals vom Standpunkt des Chirurgen aus. Langenbecks, Arch. klin. Chir., 188, 36-64.

Kapp, R. W., and Pagtalunan, R. J. G. (1961). Eosinophilic gastroduodenopathy. Ohio St. med. J., 57, 157-160.

Lynch, M. J. G., Hutchinson, W. E., and Sprague, J. D. (1956). Pyloric obstruction due to muscular hypertrophy and massive eosinophil infiltration. Gastroenterology, 31, 571-580.

McCune, W. S., Cusack, M., and Newman, W. (1955). Eosinophilic gastroduodenitis with pyloric obstruction. Ann. Surg., 142, $510-518$.

Märki, H. H. (1954). Eosinophile Granulome des Magens. Schweiz. med. Wschr., 84, 1269-1272.

Moloney, G. E. (1949). Pyloric hypertrophy with eosinophil infiltration. Lancet, 1, 412.

Orr, I. M., Miller, A. A., and Russell, J. Y. W. (1954). Eosinophilic infiltration of the stomach and bowel. Postgrad. med. J., 30, 485-493.

Ruzic, J. P., Dorsey, J. M., Huber, H. L., and Armstrong, S. H., Jr. (1952). Gastric lesion of Loeffier's syndrome. J. Amer. med. Ass., 149, 534-537.

Schneider, H., and Dailey, M. E. (1948). An unusual type of gastritis. Gastroenterology, 10, 727-730.

Spencer, J. R., Comfort, M. W., and Dahlin, D. C. (1950). Eosinophilic infiltration of the stomach and bowel associated with pyloric obstruction and recurrent eosinophilia. Gastroenterology, 15, 505-513.

Swarts, J. M., and Young, J. M. (1955). Primary infiltrative eosinophilic gastritis, enteritis, and peritonitis. Ibid., 28, 431-452.

Taccani, C. (1952). Granuloma eosinofilo dell 'ileo Chirurgia (Milano), 7, 454-460.

Weeks, D. L., Jr., and Glenn, F. (1961). Eosinophilic granuloma of the stomach. Amer. J. Surg., 101, 516-520. 